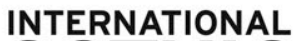 GOTHIC
}

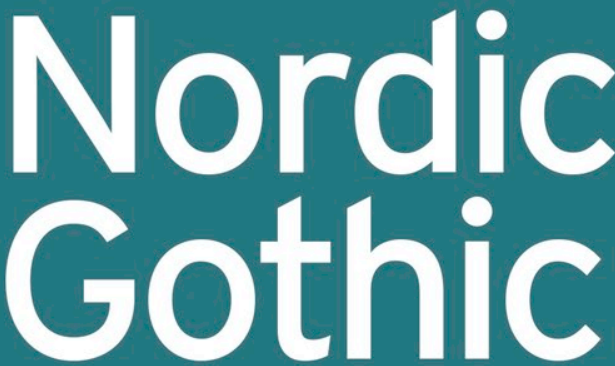

Maria Holmgren Troy, Johan Höglund, Yvonne Leffler and Sofia Wijkmark

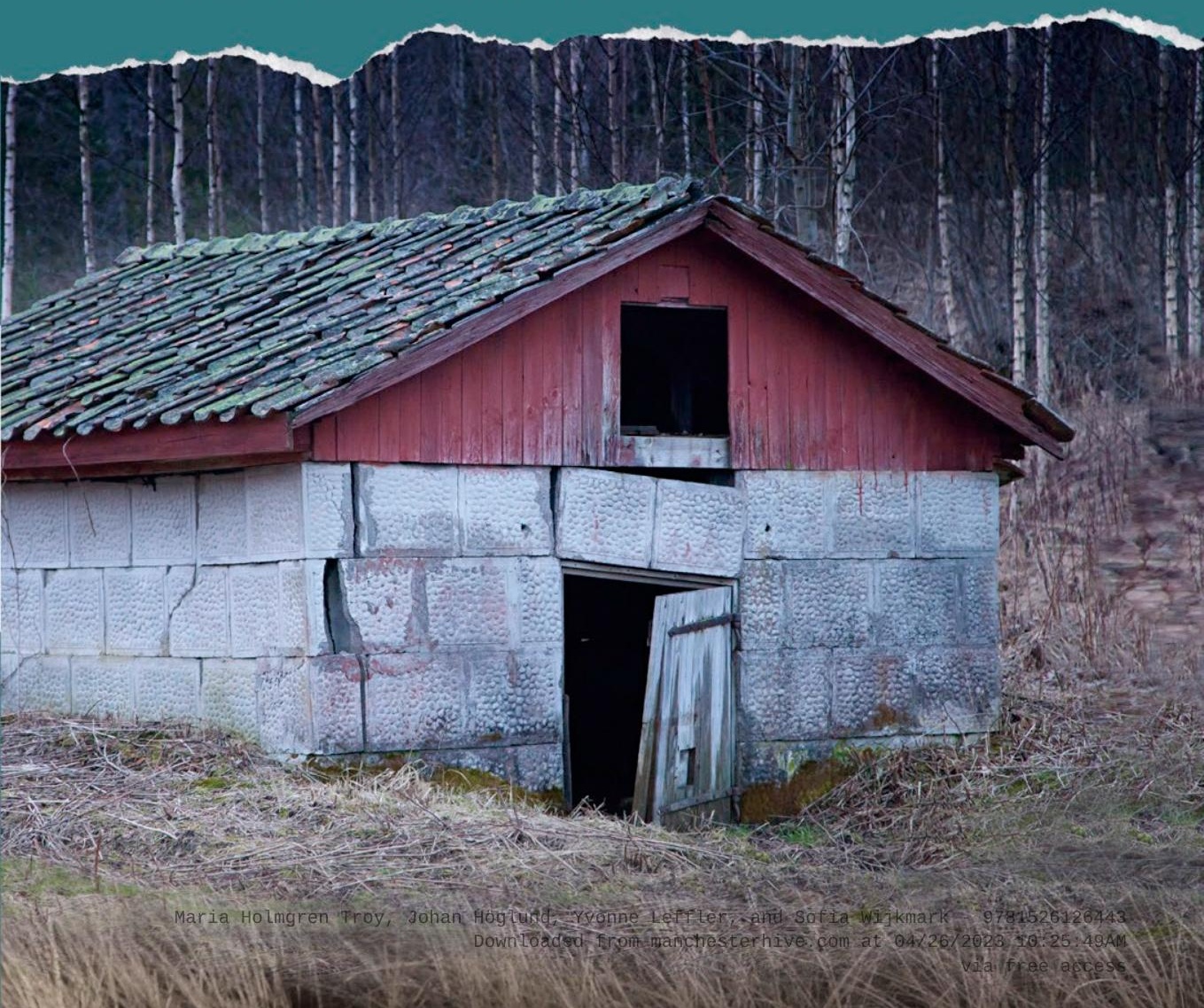




\section{Nordic Gothic}

\section{MANCHESTER 1824}

Manchester University Press

Maria Holmgren Troy, Johan Höglund, Yvonne Leffler, and Sofia Wijkmark - 9781526126443 Downloaded from manchesterhive.com at 04/26/2023 10:25:49AM 


\section{Mresentrovan GOTHIC}

\section{The Series' Board of General Editors}

Elisabeth Bronfen, University of Zurich, Switzerland Steven Bruhm, University of Western Ontario, Canada

Ken Gelder, University of Melbourne, Australia Jerrold Hogle, University of Arizona, USA (Chair) Avril Horner, Kingston University, UK William Hughes, Bath Spa University, UK

\section{The Editorial Advisory Board}

Glennis Byron, University of Stirling, Scotland Robert Miles, University of Victoria, Canada David Punter, University of Bristol, England Andrew Smith, University of Sheffield, England Anne Williams, University of Georgia, USA

Previously published

Neoliberal Gothic: international Gothic in the neoliberal age Edited by Linnie Blake and Agnieszka Soltysik Monnet

Monstrous media/spectral subjects: imaging Gothic from the nineteenth century to the present

Edited by Fred Botting and Catherine Spooner

Globalgothic Edited by Glennis Byron

The Gothic and death Edited by Carol Margaret Davison

Suicide and the Gothic Edited by William Hughes and Andrew Smith

EcoGothic Edited by Andrew Smith and William Hughes 


\section{Nordic Gothic}

Maria Holmgren Troy, Johan Höglund, Yvonne Leffler and Sofia Wijkmark

\section{Manchester University Press}

Maria Holmgren Troy, Johan Höglund, Yvonne Leffler, and Sofia Wijkmark - 9781526126443 Downloaded from manchesterhive.com at 04/26/2023 10:25:49AM 
Copyright (C) Manchester University Press 2020

While copyright in the volume as a whole is vested in Manchester University Press, copyright in individual chapters belongs to their respective authors, and no chapter may be reproduced wholly or in part without the express permission in writing of both author and publisher.

Published by Manchester University Press

Altrincham Street, Manchester M1 7JA

www.manchesteruniversitypress.co.uk

British Library Cataloguing-in-Publication Data

A catalogue record for this book is available from the British Library

ISBN 9781526126436 hardback

First published 2020

The publisher has no responsibility for the persistence or accuracy of URLs for any external or third-party internet websites referred to in this book, and does not guarantee that any content on such websites is, or will remain, accurate or appropriate.

Cover photograph by Andreas Lind

Typeset

by Toppan Best-set Premedia Limited 